\title{
Zika virus reservoirs: Implications for transmission, future outbreaks, drug and vaccine development [version 1; peer
}

\section{review: 2 approved]}

\author{
Raj Kalkeri@1, Krishna K. Murthy² \\ ${ }^{1}$ Infectious Diseases Research, Southern Research, Frederick, MD, 21701, USA \\ 2Independent Researcher, San Antonio, TX, 78249, USA
}

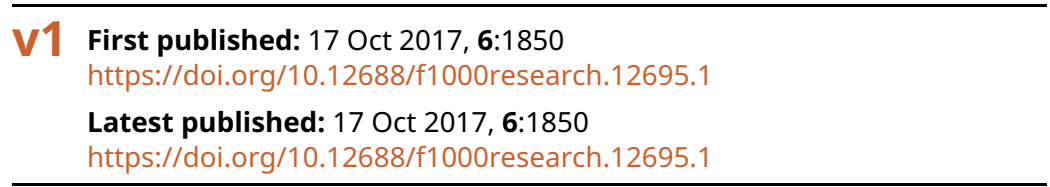

\section{Abstract}

Zika virus (ZIKV) was recently declared as a 'Global Health Emergency' by the World Health Organization. Various tissue reservoirs of ZIKV in infected humans and animals models have been observed, the implications of which are not known. Compared to other Flaviviruses, sexual transmission and persistence in the genitourinary tract seem to be unique to ZIKV. ZIKV persistence and shedding in bodily secretions (e.g. saliva, semen) is a concern for potential disease spread and could pose challenges in diagnosis, regulatory guidelines and drug/vaccine development. Murine and non-human primate models could be useful to study the role of tissue reservoirs in the development of prophylactic or therapeutic strategies. There is a need for metaanalysis of the ZIKV infection and virus shedding data from infected patients and ZIKV animal models, and additional research is needed to fully comprehend the long term implications of tissue reservoirs on ZIKV disease pathogenesis and biology.

Keywords

Zika, Persistence, transmission, tissue reservoirs, drug and vaccine development

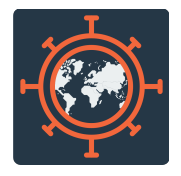

This article is included in the Emerging Diseases and Outbreaks gateway.

\author{
Open Peer Review \\ Approval Status \\ 1 \\ 2 \\ version 1 \\ 17 Oct 2017

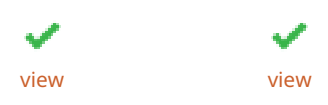 \\ 1. Sunil K Joshi D, Old Dominion University, \\ Norfolk, USA \\ 2. Michael P Busch BD, Blood Systems \\ Research Institute, San Francisco, USA \\ University of California, San Francisco, USA \\ Mars Stone, Blood Systems Research \\ Institute, San Francisco, USA \\ Any reports and responses or comments on the \\ article can be found at the end of the article.
}


Corresponding author: Raj Kalkeri (rkalkeri@southernresearch.org)

Author roles: Kalkeri R: Conceptualization, Writing - Original Draft Preparation, Writing - Review \& Editing; Murthy KK:

Conceptualization, Writing - Review \& Editing

Competing interests: No competing interests were disclosed.

Grant information: The author(s) declared that no grants were involved in supporting this work.

Copyright: @ 2017 Kalkeri R and Murthy KK. This is an open access article distributed under the terms of the Creative Commons

Attribution License, which permits unrestricted use, distribution, and reproduction in any medium, provided the original work is properly cited.

How to cite this article: Kalkeri R and Murthy KK. Zika virus reservoirs: Implications for transmission, future outbreaks, drug and vaccine development [version 1; peer review: 2 approved] F1000Research 2017, 6:1850

https://doi.org/10.12688/f1000research.12695.1

First published: 17 Oct 2017, 6:1850 https://doi.org/10.12688/f1000research.12695.1 


\section{Introduction}

After the recent outbreak of Zika virus (ZIKV) infection in Brazil and other countries, multiple studies have been published regarding various tissue reservoirs, including the eyes, nervous system, genitourinary tracts and placenta (Table 1). A recent report of ZIKV transmission in renal and liver transplant patients with abnormal graft functions ${ }^{1}$ poses a new challenge in screening organs intended for transplants and monitoring transplanted patients. Considering such new concerns for ZIKV, we have reviewed the existing literature about ZIKV tissue reservoirs in this article and provide our analysis of the potential impact of ZIKV reservoirs on transmission and challenges in development of medical countermeasures against ZIKV.

\section{ZIKV tissue reservoirs}

The role of immune-privileged sites (e.g. eyes, testes, fetal brain, and placenta) in harboring ZIKV has been previously reported ${ }^{2}$, contributing to the viral persistence in these tissues. Successful infection and amplification of ZIKV in vitro in primary cell cultures derived from the placenta ${ }^{3}$, kidney ${ }^{4}$, nervous tissue ${ }^{5}$, and amplification found in the brain of severely damaged fetus ${ }^{6}$ suggests the potential ability of these tissue reservoirs to support both infection and amplification of ZIKV. Furthermore, that the reservoir-derived virus is infectious has been confirmed by sexual- and or transplantrelated transmission of infection from non-viremic partners or donors ${ }^{7}$. These studies raise the possibility that individuals with ZIKV reservoirs could serve as a potential source of endemic and recurrent outbreaks of infection. In addition, the prevalence of such reservoirs in immune compromised patients ${ }^{8}$ is a major concern as the disease could spread to other organs rapidly and run a more aggressive course, in the absence of immune defenses of the body.

\section{ZIKV in body secretions}

Interestingly, besides tissue reservoirs, few reports have been successful in the detection of ZIKV in the bodily secretions of infected patients, such as saliva ${ }^{9,10}$ urine ${ }^{9,11}$, semen and vaginal secretions ${ }^{12-14}$, breast milk ${ }^{15}$ and conjunctival fluid ${ }^{16}$. Semen and vaginal secretions are already reported to be involved in sexual transmission of $\mathrm{ZIKV}^{7}$ in humans. Despite a recent report about the persistence of ZIKV in the semen for more than 6 months ${ }^{17}$, the duration of the persistence in other bodily secretions (urine, saliva etc) is unclear at this time. Careful evaluation of the duration of the ZIKV shedding and its role in non-sexual transmission needs to be conducted.

Table 1. ZIKV reservoirs reported in humans.

\begin{tabular}{|l|l|}
\hline Organ & Confirmed in animal models \\
\hline Eyes $^{16,42}$ & 25 \\
\hline Kidney $^{11}$ & $\begin{array}{l}\text { Due to detection in urine and } \\
\text { translation from mice studies. }\end{array}$ \\
\hline $\begin{array}{l}\text { Nervous } \\
\text { Tissue }^{6}\end{array}$ & 24,27 \\
\hline Testes $^{13,17}$ & $\begin{array}{l}\text { Due to detection in semen and } \\
\text { translation from mice } \text { studies }^{2,18,23} .\end{array}$ \\
\hline Placenta $^{3,6}$ & 22,43 \\
\hline
\end{tabular}

\section{In vivo models for ZIKV tissue reservoirs}

Animal models for ZIKV have further confirmed some of these tissue reservoirs ${ }^{18-25}$. Tang et al. demonstrated the persistence of $\mathrm{ZIKV}$ in the vaginal washes as late as 10 days post-infection in lethal and sub-lethal mouse models after intravaginal inoculation of ZIKV ${ }^{26}$. Ifnar1(-/-) mice showed sustained high viral loads in the brain, spinal cord and testes, confirming these tissue reservoirs ${ }^{21}$. AG129 mice showed severe pathologies in the muscle and brain ${ }^{27}$, confirming the presence of these reservoirs in mouse models.

ZIKV was shown to persist in the cerebrospinal fluid (CSF) and lymph nodes (LN) of infected rhesus monkeys weeks after virus clearance from the peripheral blood, urine and mucosal secretions ${ }^{28}$. Similar observation of longer persistence of ZIKV in the hemolymphatic tissue of non-pregnant rhesus macaques infected with 2015 Brazilian ZIKV isolate was observed by Coffey and colleagues ${ }^{29}$. ZIKV was also observed in the lacrimal fluid and parotid glands $\mathrm{s}^{30}$ of rhesus macaques after subcutaneous infection. ZIKV RNA was detectable in saliva, semen, urine of both rhesus and cynomolgus macaques ${ }^{20}$. ZIKV infection in the pregnant rhesus macaques showed longer duration of persistence (57 days) compared to normal macaques (21 days) ${ }^{31}$, suggesting differential persistence depending upon the pregnancy status.

A recent study showed the importance of autophagy on the vertical transmission of ZIKV in pregnant mice ${ }^{32}$. The authors demonstrated the activity of an autophagy inhibitor approved for use in pregnant women (hydroxychloroquine) in attenuating the placental and fetal ZIKV infection and ameliorated adverse placental and fetal outcomes. Thus animal models could prove useful to study the importance of tissue reservoirs in ZIKV biology and pathogenesis, as well as evaluation of experimental drugs and vaccines.

\section{Relationship to other Flaviviruses}

A review of the literature suggested similar tissue reservoirs observed for other Flaviviruses (Table 2). Tick-borne encephalitis, West Nile Virus and Japanese Encephalitis Virus have varying durations of persistence ${ }^{33}$. However, unlike other Flaviviruses, sexual transmission is unique to $\mathrm{ZIKV}$ infections ${ }^{7}$. This is not surprising due to ZIKV's persistence in the genitourinary tract $^{34}$. The presence of ZIKV in semen is without apparent disease symptoms ${ }^{35}$, and can be for a period of more than 6 months ${ }^{17}$. This indicates a need for inclusion of ZIKV in the screening panel for semen donors in

Table 2. Tissue reservoirs for other Flaviviruses.

\begin{tabular}{|l|l|l|}
\hline Virus & Tissue/Secretion & Duration \\
\hline $\begin{array}{l}\text { Siberian Tick Borne } \\
\text { encephalitis (TBEV) }\end{array}$ & $\begin{array}{l}\text { Brain/Nervous } \\
\text { system }\end{array}$ & 10 years $^{44}$ \\
\hline $\begin{array}{l}\text { Japanese Encephalitis } \\
\text { Virus (JEV) }\end{array}$ & CSF & $\begin{array}{l}>3 \text { weeks post- } \\
\text { infection }\end{array}$ \\
\hline West Nile Virus (WNV) & PBMCs & $\begin{array}{l}\text { 8-9 months after } \\
\text { infection }\end{array}$ \\
\hline & $\begin{array}{l}\text { Blood/organ } \\
\text { transplants }\end{array}$ & $>40$ days $^{47-50}$ \\
\hline Urine & 6.5 years $^{51}$ \\
\hline
\end{tabular}


addition to the current viruses in the panel (i.e. hepatitis B, C and HIV, as per the guidelines of American Society for Reproductive Medicine and Food and Drug Administration).

Another potential concern of ZIKV tissue reservoirs (with low levels of ZIKV) is triggering of sub-neutralizing antibodies leading to antibody-dependent enhancement (ADE) of subsequent Flavivirus infections and potential interplay with other mosquito born Flaviviruses. Recently, ADE of ZIKV by sub-neutralizing Dengue virus antibodies has been reported ${ }^{36,37}$. Considering the similar target organ affinity (e.g. nervous tissue) observed for other Flaviviruses (e.g. West Nile Virus, Dengue Virus) ${ }^{33}$, such a concern cannot be ruled out.

\section{Challenges for the development of countermeasures against ZIKV}

The presence of tissue reservoirs and detection of the virus for varying periods of duration, after initial infection, in the absence of the apparent symptoms, poses new challenges for screening of populations. In 2013 during the French Polynesian Zika outbreak, differential virus positivity was observed between the serum, saliva and urine samples collected from 182 patients. Saliva but not serum, from 35 patients was Zika positive. In contrast, serum but not saliva from 16 other patients was Zika positive ${ }^{37}$. Considering such variability in different biological samples from patients, paired serum and urine samples are considered to be of primary diagnostic importance (CDC guidance for US laboratories testing for Zika virus infections).

Interestingly, in animal studies, low levels of Zika were observed in the body secretions compared to the serum ${ }^{38}$. Such low levels of ZIKV in the body secretions near the detection limits and invasive processes needed to collect samples (eg. CSF, nervous tissue), suggest currently available detection assays may or may not be suitable to identify persistent ZIKV infections and quantify the tissue reservoirs. As per the CDC information, there are currently no FDA-authorized assays for Zika virus testing of tissue specimens, including fetal and placental tissue, suggesting the need for additional efforts towards such diagnostic assays.

FDA has issued Emergency Use authorization of several diagnostic tools for Zika virus. These include both antibody based and nucleic acid testing (NAT) kits, which are currently distributed to qualified laboratories by the CDC (Table 3 ).

Antibody based ZIKV detection methods are suggestive of past or recent exposure to Zika and may not necessarily indicate the presence of the virus in the body. In addition, antibody based methods are suitable only for serum, whereas NAT might be suitable for all types of samples including serum and bodily fluids. Due to

Table 3. Zika virus diagnostic test kits available through Emergency Use Authorization of the FDA.

\begin{tabular}{|c|c|c|}
\hline Kit & Detection method & Vendor \\
\hline DPP Zika IgM Assay System & Antibody & Chembio Diagnostic Systems, Inc. \\
\hline ADVIA Centaur Zika test & Antibody & Siemens Healthcare Diagnostics Inc \\
\hline Cll-ArboViroPlex rRT-PCR Assay & NAT & Columbia University \\
\hline TaqPath Zika Virus Kit & NAT & Thermo Fisher Scientific \\
\hline LIAISON ${ }^{\circledR}$ XL Zika Capture IgM Assay & Antibody & DiaSorin Incorporated \\
\hline Gene-RADAR ${ }^{\circledR}$ Zika Virus Test & NAT & Nanobiosym Diagnostics, Inc \\
\hline Zika ELITe MGB ${ }^{\circledast}$ Kit U.S. & NAT & ELITechGroup Inc. Molecular Diagnostics \\
\hline Abbott RealTime Zika & NAT & Abbott Molecular Inc. \\
\hline Zika Virus Detection by RT-PCR Test & NAT & ARUP Laboratories \\
\hline Sentosa $^{\circledast}$ SA ZIKV RT-PCR Test & NAT & Vela Diagnostics USA, Inc. \\
\hline ZIKV Detect ${ }^{T M}$ IgM Capture ELISA & Antibody & InBios International, Inc \\
\hline xMAP ${ }^{\circledR}$ MultiFLEX'⿳亠口冋 Zika RNA Assay & NAT & Luminex Corporation \\
\hline $\begin{array}{l}\text { VERSANT }{ }^{\circledR} \text { Zika RNA } 1.0 \text { Assay } \\
\text { (kPCR) Kit }\end{array}$ & NAT & Siemens Healthcare Diagnostics Inc \\
\hline Zika Virus Real-time RT-PCR Test & NAT & Viracor Eurofins \\
\hline Aptima $^{\circledR}$ Zika Virus Assay & NAT & Hologic, Inc \\
\hline RealStar ${ }^{\circledR}$ Zika Virus RT-PCR Kit U.S. & NAT & Altona Diagnostics \\
\hline $\begin{array}{l}\text { Zika Virus RNA Qualitative Real-Time } \\
\text { RT-PCR }\end{array}$ & NAT & Quest Diagnostics Infectious Disease, Inc \\
\hline Zika MAC-ELISA & Antibody & CDC \\
\hline Trioplex Real-time RT-PCR Assay & NAT & CDC \\
\hline
\end{tabular}

NAT: Nucleic Acid based detection Test 
the direct detection of the virus, NAT-based detection kits might be well suited for the identification of persistent infections. A rapid and high-throughput method for detecting ZIKV RNA using transcription-mediated amplification technology, based Aptima Zika virus assay (Hologic, Marlborough, MA) is described to detect 11.5 to 17.5 genome copy equivalents in serum and urine ${ }^{39}$. A recent report suggests the utility of isothermal amplification based point-of-care diagnostic technology for rapid detection of ZIKV in the saliva ${ }^{40}$. The performance of such kits in the clinic remains to be seen. Additional research might shed some light on the acceptable standard for such an effort.

ZIKV tissue reservoirs bring in additional challenges for drug or vaccine development. According to the WHO vaccine pipeline tracker, there are many ZIKV vaccine candidates currently being tested. These include four DNA vaccines (one from GeneOne Life Sciences and three from NIAID), four inactivated whole virus vaccines ( 3 from NIAID and 1 from BIDMC), one peptide (NIH), one mRNA (Moderna), and one recombinant MV-Zika-101 (Themis Bioscience). Two of these candidates- VRC-ZKADNA090-00-VP (NIAID) and mRNA 1325 (Moderna) are currently recruiting patients for phase 2 trials.

To be effective, potential treatments for ZIKV might have to achieve appropriate tissue concentrations in these reservoirs. This might be limited by sufficient bioavailability of therapeutics in the tissue reservoirs and penetration of the blood brain barrier (BBB). Similar concerns for placental barrier and challenging anatomical locations (e.g. the eyes, kidney, and testes) create additional hurdles for elimination of viral reservoirs. Prophylactic vaccine strategies should be capable of not only preventing infection, but also prevent the establishment of viral reservoirs. In addition, potential vaccine candidates should be capable of inducing a potent neutralizing antibody response to mitigate the possibility of ADE mentioned above.

\section{Concluding remarks}

ZIKV animal models (mice, monkeys) could serve as valuable tools in evaluating the efficacy of therapeutic and prophylactic strategies in eliminating ZIKV tissue reservoirs and prevent shedding of the virus. Additional questions such as relative difference between ZIKV strains to persist in the tissue reservoirs, relative size of different tissue reservoirs (brain, eyes, testes), role of host factors in persistence (tissue reservoir formation), kinetics of virus persistence, and phenotypic and genotypic characterization of the virus in tissue reservoirs, will require additional studies. Formation of ZIKV task force by the Global Virus Networks ${ }^{41}$ is a welcome move that might be helpful in addressing some of these issues. There is a need for a publically available database (suitable for meta-analysis) to compare long-term kinetics of ZIKV infections and persistence in both animal models and clinical settings. Together with additional research, this might reveal the impact of ZIKV tissue reservoirs on future outbreaks, and drug and vaccine development.

\section{Competing interests}

No competing interests were disclosed.

\section{Grant information}

The author(s) declared that no grants were involved in supporting this work.
1. Nogueira ML, Estofolete CF, Terzian AC, et al:: Zika Virus Infection and Solid Organ Transplantation: A New Challenge. Am J Transplant. 2017; 17(3): 791-795. PubMed Abstract | Publisher Full Text

2. Ma W, Li S, Ma S, et al:: Zika Virus Causes Testis Damage and Leads to Male Infertility in Mice. Cell. 2016; 167(6): 1511-1524.e10. PubMed Abstract | Publisher Full Text

3. Aagaard KM, Lahon A, Suter MA, et al.: Primary Human Placental Trophoblasts are Permissive for Zika Virus (ZIKV) Replication. Sci Rep. 2017; 7: 41389. PubMed Abstract | Publisher Full Text | Free Full Text

4. Alcendor DJ: Zika Virus Infection of the Human Glomerular Cells: Implications for Viral Reservoirs and Renal Pathogenesis. J Infect Dis. 2017; 216(2): 162-171. PubMed Abstract | Publisher Full Text

5. Mladinich MC, Schwedes J, Mackow ER: Zika Virus Persistently Infects and Is Basolaterally Released from Primary Human Brain Microvascular Endothelia Cells. mBio. 2017; 8(4): pii: e00952-17. PubMed Abstract | Publisher Full Text | Free Full Text

6. Bhatnagar J, Rabeneck DB, Martines RB, et al:: Zika Virus RNA Replication and Persistence in Brain and Placental Tissue. Emerg Infect Dis. 2017; 23(3): 405-414.

PubMed Abstract | Publisher Full Text | Free Full Text

7. Foy BD, Kobylinski KC, Chilson Foy JL, et al.: Probable non-vector-borne transmission of Zika virus, Colorado, USA. Emerg Infect Dis. 2011; 17(5): 880-2. PubMed Abstract | Publisher Full Text | Free Full Text

8. Calvet GA, Filippis AM, Mendonça MC, et al:: First detection of autochthonous Zika virus transmission in a HIV-infected patient in Rio de Janeiro, Brazil. J Clin Virol. 2016; 74: 1-3.

PubMed Abstract | Publisher Full Text
9. Barzon L, Pacenti M, Franchin E, et al.: Infection dynamics in a traveller with persistent shedding of Zika virus RNA in semen for six months after returning from Haiti to Italy, January 2016. Euro Surveill. 2016; 21(32): 30316. PubMed Abstract | Publisher Full Text | Free Full Text

10. Liuzzi G, Puro V, Lanini S, et al:: Zika virus and microcephaly: is the correlation causal or coincidental? New Microbiol. 2016; 39(2): 83-5. PubMed Abstract

11. Rossini G, Gaibani P, Vocale C, et al.: Comparison of Zika virus (ZIKV) RNA detection in plasma, whole blood and urine - Case series of travel-associated ZIKV infection imported to Italy, 2016. J Infect. 2017; 75(3): 242-245. PubMed Abstract | Publisher Full Text

12. Froeschl G, Huber K, von Sonnenburg F, et al:: Long-term kinetics of Zika virus RNA and antibodies in body fluids of a vasectomized traveller returning from Martinique: a case report. BMC Infect Dis. 2017; 17(1): 55. PubMed Abstract | Publisher Full Text | Free Full Text

13. Nicastri E, Castilletti C, Liuzzi G, et al:: Persistent detection of Zika virus RNA in semen for six months after symptom onset in a traveller returning from Haiti to Italy, February 2016. Euro Surveill. 2016; 21(32): 30314. PubMed Abstract | Publisher Full Text | Free Full Text

14. Nicastri E, Castilletti $C$, Balestra $P$, et al:: Zika Virus Infection in the Central Nervous System and Female Genital Tract. Emerg Infect Dis. 2016; 22(12): 2228-2230.

PubMed Abstract | Publisher Full Text | Free Full Text

15. Sotelo JR, Sotelo AB, Sotelo FJB, et al.: Persistence of Zika Virus in Breast Milk after Infection in Late Stage of Pregnancy. Emerg Infect Dis. 2017; 23(5): 856-857.

PubMed Abstract | Publisher Full Text | Free Full Text 
16. Sun J, Wu, Zhong $\mathrm{H}$, et al.: Presence of Zika Virus in Conjunctival Fluid. JAMA Ophthalmol. 2016; 134(11): 1330-1332.

PubMed Abstract | Publisher Full Tex

17. Atkinson B, Thorburn F, Petridou C, et al.: Presence and Persistence of Zika Virus RNA in Semen, United Kingdom, 2016. Emerg Infect Dis. 2017; 23(4): 611-615.

PubMed Abstract | Publisher Full Text | Free Full Text

18. Govero J, Esakky P, Scheaffer SM, et al:: Zika virus infection damages the testes in mice. Nature. 2016; 540(7633): 438-442.

PubMed Abstract | Publisher Full Text | Free Full Tex

19. Adams Waldorf KM, Stencel-Baerenwald JE, Kapur RP, et al.: Fetal brain lesions after subcutaneous inoculation of Zika virus in a pregnant nonhuman primate. Nat Med. 2016; 22(11): 1256-1259.

PubMed Abstract | Publisher Full Text | Free Full Text

20. Osuna CE, Lim SY, Deleage C, et al:: Zika viral dynamics and shedding in rhesus and cynomolgus macaques. Nat Med. 2016; 22(12): 1448-1455. PubMed Abstract | Publisher Full Text | Free Full Text

21. Lazear HM, Govero J, Smith AM, et al:: A Mouse Model of Zika Virus Pathogenesis. Cell Host Microbe. 2016; 19(5): 720-30. PubMed Abstract | Publisher Full Text | Free Full Text

22. Miner JJ, Cao B, Govero J, et al.: Zika Virus Infection during Pregnancy in Mice Causes Placental Damage and Fetal Demise. Cell. 2016; 165(5): 1081-91. PubMed Abstract | Publisher Full Text | Free Full Text

23. Uraki R, Hwang J, Jurado KA, et al: Zika virus causes testicular atrophy. Sci Adv. 2017; 3(2): e1602899.

PubMed Abstract | Publisher Full Text | Free Full Text

24. Yockey LJ, Varela L, Rakib T, et al:: Vaginal Exposure to Zika Virus during Pregnancy Leads to Fetal Brain Infection. Cell. 2016; 166(5): 1247-1256.e4. PubMed Abstract | Publisher Full Text | Free Full Text

25. Miner JJ, Sene A, Richner JM, et al:: Zika Virus Infection in Mice Causes Panuveitis with Shedding of Virus in Tears. Cell Rep. 2016; 16(12): 3208-18. PubMed Abstract | Publisher Full Text | Free Full Text

26. Tang WW, Young MP, Mamidi A, et al:: A Mouse Model of Zika Virus Sexua Transmission and Vaginal Viral Replication. Cell Rep. 2016; 17(12): 3091-3098. PubMed Abstract | Publisher Full Text | Free Full Text

27. Aliota MT, Caine EA, Walker EC, et al.: Characterization of Lethal Zika Virus Infection in AG129 Mice. PLoS Negl Trop Dis. 2016; 10(4): e0004682. PubMed Abstract | Publisher Full Text | Free Full Text

28. Aid M, Abbink P, Larocca RA, et al: Zika Virus Persistence in the Centra Nervous System and Lymph Nodes of Rhesus Monkeys. Cell. 2017; 169(4): 610-620.e14.

PubMed Abstract | Publisher Full Text | Free Full Tex

29. Coffey LL, Pesavento PA, Keesler RI, et al.: Zika Virus Tissue and Blood Compartmentalization in Acute Infection of Rhesus Macaques. PLoS One. 2017; 12(1): e0171148.

PubMed Abstract | Publisher Full Text | Free Full Text

30. Li XF, Dong HL, Huang XY, et al.: Characterization of a 2016 Clinical Isolate of Zika Virus in Non-human Primates. EBioMedicine. 2016; 12: 170-177. PubMed Abstract | Publisher Full Text | Free Full Text

31. Dudley DM, Aliota MT, Mohr EL, et al:: A rhesus macaque model of Asianlineage Zika virus infection. Nat Commun. 2016; 7: 12204. PubMed Abstract | Publisher Full Text | Free Full Text

32. Cao B, Parnell LA, Diamond MS, et al:: Inhibition of autophagy limits vertical transmission of Zika virus in pregnant mice. J Exp Med. 2017; 214(8): 2303-2313.

PubMed Abstract | Publisher Full Text | Free Full Text

33. Mlera L, Melik W, Bloom ME: The role of viral persistence in flavivirus biology. Pathog Dis. 2014; 71(2): 137-63.

PubMed Abstract | Publisher Full Text | Free Full Text

34. Paz-Bailey G, Rosenberg ES, Doyle K, et al.: Persistence of Zika Virus in Body
Fluids - Preliminary Report. N Engl J Med. 2017.

PubMed Abstract | Publisher Full Text

35. Cardona Maya WD, Du Plessis SS, Velilla PA: Semen as virus reservoir? J Assist Reprod Genet. 2016; 33(9): 1255-6.

PubMed Abstract | Publisher Full Text | Free Full Text

36. Castanha PMS, Nascimento EJM, Braga C, et al.: Dengue Virus-Specific Antibodies Enhance Brazilian Zika Virus Infection. J Infect Dis. 2017; 215(5): 781-785.

PubMed Abstract | Publisher Full Text

37. Musso D, Roche C, Nhan TX, et al:: Detection of Zika virus in saliva. J Clin Virol. 2015; 68: 53-5.

PubMed Abstract | Publisher Full Text

38. Koide F, Goebel S, Snyder B, et al.: Development of a Zika Virus Infection Model in Cynomolgus Macaques. Front Microbiol. 2016; 7: 2028.

PubMed Abstract | Publisher Full Text | Free Full Text

39. Ren P, Ortiz DA, Terzian ACB, et al.: Evaluation of Aptima Zika Virus Assay. J Clin Microbiol. 2017; 55(7): 2198-2203.

PubMed Abstract | Publisher Full Text | Free Full Text

40. Mauk MG, Song J, Bau HH, et al.: Point-of-Care Molecular Test for Zika Infection. Clin Lab Int. 2017; 41: 25-27.

PubMed Abstract | Free Full Text

41. Aliota MT, Bassit L, Bradrick SS, et al.: Zika in the Americas, year 2: What have we learned? What gaps remain? A report from the Global Virus Network. Antiviral Res. 2017; 144: 223-246.

PubMed Abstract | Publisher Full Text

42. Kodati S, Palmore TN, Spellman FA, et al:: Bilateral posterior uveitis associated with Zika virus infection. Lancet. 2017; 389(10064): 125-126. PubMed Abstract | Publisher Full Text

43. Calvet G, Aguiar RS, Melo ASO, et al.: Detection and sequencing of Zika virus from amniotic fluid of fetuses with microcephaly in Brazil: a case study. Lance Infect Dis. 2016; 16(6): 653-60.

PubMed Abstract | Publisher Full Text

44. Gritsun TS, Frolova TV, Zhankov Al, et al:: Characterization of a siberian virus isolated from a patient with progressive chronic tick-borne encephalitis. $J$ Virol. 2003; 77(1): 25-36.

PubMed Abstract | Publisher Full Text | Free Full Text

45. Ravi V, Desai AS, Shenoy PK, et al.: Persistence of Japanese encephalitis virus in the human nervous system. J Med Virol. 1993; 40(4): 326-9.

PubMed Abstract | Publisher Full Text

46. Sharma S, Mathur A, Prakash V, et al.: Japanese encephalitis virus latency in peripheral blood lymphocytes and recurrence of infection in children. Clin Exp Immunol. 1991; 85(1): 85-9.

PubMed Abstract | Publisher Full Text | Free Full Text

47. Montgomery SP, Brown JA, Kuehnert M, et al:: Transfusion-associated transmission of West Nile virus, United States 2003 through 2005. Transfusion. 2006; 46(12): 2038-46.

PubMed Abstract | Publisher Full Text

48. Prince $\mathrm{HE}$, Lapé-Nixon $\mathrm{M}$, Yeh $\mathrm{C}$, et al:: Persistence of antibodies to West Nile virus nonstructural protein 5. J Clin Virol. 2008; 43(1): 102-6. PubMed Abstract | Publisher Full Text

49. Pealer LN, Marfin AA, Petersen LR, et al.: Transmission of West Nile virus through blood transfusion in the United States in 2002. N Engl J Med. 2003; 349(13): 1236-45.

PubMed Abstract | Publisher Full Text

50. Busch MP, Kleinman $\mathrm{SH}$, Tobler $\mathrm{LH}$, et al: Virus and antibody dynamics in acute west nile virus infection. $J$ Infect Dis. 2008; 198(7): 984-93. PubMed Abstract | Publisher Full Text

51. Murray K, Walker C, Herrington E, et al.: Persistent infection with West Nile virus years after initial infection. $J$ Infect Dis. 2010; 201(1): 2-4. PubMed Abstract | Publisher Full Text | Free Full Text 


\title{
Open Peer Review
}

\section{Current Peer Review Status:}

\section{Version 1}

Reviewer Report 27 November 2017

https://doi.org/10.5256/f1000research.13748.r28041

(C) 2017 Busch $\mathbf{M}$ et al. This is an open access peer review report distributed under the terms of the Creative Commons Attribution License, which permits unrestricted use, distribution, and reproduction in any medium, provided the original work is properly cited.

\author{
Michael P Busch \\ 1 Blood Systems Research Institute, San Francisco, California, USA \\ 2 University of California, San Francisco, California, USA
}

\section{Mars Stone}

Blood Systems Research Institute, San Francisco, California, USA

Kalkeri and Murthy offer a valuable brief review of tissue reservoirs and its implications for transmission and treatment of Zika infection. Since studies of persistence of Zika virus infection in tissue reservoirs are limited in humans and hence not well understood, insights from rhesus macaque and mouse models of Zika infection are important to characterize persistence and its relevance to transmission and pathogenesis, as well as addressing challenges in treatment and diagnosis.

Not mentioned in the review is the finding of persistence in whole blood, and in particular RBCs, after clearance from plasma (several publications) and the potential risk for transmission through bone marrow, cord blood and peripheral blood stem cell transplants. Transfusion transmission has been documented as another mode of transmission.

Co-circulation of related Flaviviruses in Zika endemic areas is a concern for ADE of subsequent antigenically similar viruses as mentioned in the review. However evidence for ADE in humans is lacking. ADE from previous Dengue virus exposure has been demonstrated in vitro and in mouse models, but not in rhesus macaques and is not confirmed by human epidemiological studies based on several recent publications. Conclusions about ADE should therefore be made with caution.

Briefly mentioned are issues with serological diagnostics, which are challenging due to cross reactivity and anamnestic response in serial infections by similar viruses as well as Arboviral vaccination. There are limitations with many existing assays, however newer assays have been more successful in differentiating Zika from Dengue. Access to samples from ZIKV/DENV infected macaques could allow for advances in this important area. 
Reference 37 (ZIKV in saliva) is incorrectly placed in the context of ADE second paragraph of page 3.

Suggest adding references at the bottom.

\section{References}

1. Musso D, Richard V, Teissier A, Stone M, et al.: Detection of Zika virus RNA in semen of asymptomatic blood donors.Clin Microbiol Infect. 2017. PubMed Abstract | Publisher Full Text 2. Musso D, Roche $C$, Robin E, Nhan T, et al.: Potential sexual transmission of Zika virus.Emerg Infect Dis. 2015; 21 (2): 359-61 PubMed Abstract | Publisher Full Text

3. Musso D, Roche C, Nhan TX, Robin E, et al.: Detection of Zika virus in saliva.J Clin Virol. 2015; 68: 53-5 PubMed Abstract | Publisher Full Text

4. Best K, Guedj J, Madelain V, de Lamballerie X, et al.: Zika plasma viral dynamics in nonhuman primates provides insights into early infection and antiviral strategies.Proc Natl Acad Sci U S A. 2017; 114 (33): 8847-8852 PubMed Abstract | Publisher Full Text

5. Aid M, Abbink P, Larocca RA, Boyd M, et al.: Zika Virus Persistence in the Central Nervous System and Lymph Nodes of Rhesus Monkeys.Cell. 2017; 169 (4): 610-620.e14 PubMed Abstract | Publisher Full Text

6. Machado C, Pereira B, Felix A, Oliveira M, et al.: Zika and chikungunya virus infections in hematopoietic stem cell transplant recipients and oncohematological patients. Blood Advances. 2017; 1 (10): 624-627 Publisher Full Text

7. Mansuy JM, Mengelle C, Pasquier C, Chapuy-Regaud S, et al.: Zika Virus Infection and Prolonged Viremia in Whole-Blood Specimens.Emerg Infect Dis. 23 (5): 863-865 PubMed Abstract | Publisher Full Text

8. Murray KO, Gorchakov R, Carlson AR, Berry R, et al.: Prolonged Detection of Zika Virus in Vaginal Secretions and Whole Blood.Emerg Infect Dis. 23 (1): 99-101 PubMed Abstract | Publisher Full Text 9. McCracken MK, Gromowski GD, Friberg HL, Lin X, et al.: Impact of prior flavivirus immunity on Zika virus infection in rhesus macaques.PLoS Pathog. 2017; 13 (8): e1006487 PubMed Abstract | Publisher Full Text

10. Terzian A, Schanoski A, Mota M, da Silva R, et al.: Viral Load and Cytokine Response Profile Does Not Support Antibody-Dependent Enhancement in Dengue-Primed Zika Virus-Infected Patients. Clinical Infectious Diseases. 2017; 65 (8): 1260-1265 Publisher Full Text 11. Carroll T, Lo M, Lanteri M, Dutra J, et al.: Zika virus preferentially replicates in the female reproductive tract after vaginal inoculation of rhesus macaques.PLoS Pathog. 2017; 13 (7): e1006537 PubMed Abstract | Publisher Full Text

Is the topic of the review discussed comprehensively in the context of the current literature?

Yes

Are all factual statements correct and adequately supported by citations? Partly

Is the review written in accessible language? Yes

Are the conclusions drawn appropriate in the context of the current research literature? 
Yes

Competing Interests: No competing interests were disclosed.

Reviewer Expertise: Diagnostics and pthogenesis of viral and parasitic infections

We confirm that we have read this submission and believe that we have an appropriate level of expertise to confirm that it is of an acceptable scientific standard.

Reviewer Report 30 October 2017

https://doi.org/10.5256/f1000research.13748.r27070

(C) 2017 Joshi S. This is an open access peer review report distributed under the terms of the Creative Commons Attribution License, which permits unrestricted use, distribution, and reproduction in any medium, provided the original work is properly cited.

\section{Sunil K Joshi}

Cellular Immunology Lab, Frank Reidy Research Center of Bioelectrics, Old Dominion University, Norfolk, VA, USA

This report is very important in terms of ZIKA as reservoir. Authors have done excellent work in writing this unique review and will enhance our understanding of ZIKA transmission via reservoir infection.

Recent reports indicating that detection of ZIKV in the bodily secretions of infected patients, such as saliva, urine, semen and vaginal secretions, breast milk and conjunctival fluid is an important public health concern, particularly reservoir ZIKV still can cause spread of the disease.

\section{References}

1. Munjal A, Khandia R, Dhama K, Sachan S, et al.: Advances in Developing Therapies to Combat Zika Virus: Current Knowledge and Future Perspectives.Front Microbiol. 2017; 8: 1469 PubMed Abstract | Publisher Full Text

Is the topic of the review discussed comprehensively in the context of the current literature?

Yes

Are all factual statements correct and adequately supported by citations?

Yes

Is the review written in accessible language?

Yes

Are the conclusions drawn appropriate in the context of the current research literature? Yes 
Competing Interests: No competing interests were disclosed.

Reviewer Expertise: Cellular immunology, Dendritic cell manipulations in Cancer and Infectious Diseases.

I confirm that I have read this submission and believe that I have an appropriate level of expertise to confirm that it is of an acceptable scientific standard.

The benefits of publishing with F1000Research:

- Your article is published within days, with no editorial bias

- You can publish traditional articles, null/negative results, case reports, data notes and more

- The peer review process is transparent and collaborative

- Your article is indexed in PubMed after passing peer review

- Dedicated customer support at every stage

For pre-submission enquiries, contact research@f1000.com 